\title{
Productivity and residual benefits of grain legumes to sorghum under semi-arid conditions in southwestern Zimbabwe
}

\author{
Bongani Ncube • Steve J. Twomlow • \\ Mark T. van Wijk • John P. Dimes • Ken E. Giller
}

Received: 21 March 2007 / Accepted: 13 June 2007 / Published online: 12 September 2007

(C) Springer Science + Business Media B.V. 2007

\begin{abstract}
The productivity and residual benefits of four grain legumes to sorghum (Sorghum bicolor) grown in rotation were measured under semi-arid conditions over three cropping seasons. Two varieties of each of the grain legumes; cowpea (Vigna unguiculata); groundnut (Arachis hypogaea); pigeon pea (Cajanus cajan); Bambara groundnut (Vigna subterranea), and sorghum were grown during the first season. The same experiment was implemented three times in different, but adjacent fields that had similar soil types. At the end of the season the original plots were split in two and residues were either removed or incorporated into the subplots. The following season sorghum was planted in all subplots. In 2002/03 (314 $\mathrm{mm}$ rainfall) cowpeas produced the largest dry grain yield (0.98 and $\left.1.36 \mathrm{t} \mathrm{ha}^{-1}\right)$ among the legumes. During the wettest year (2003/04, $650 \mathrm{~mm}$ rainfall) groundnut had the highest yields (0.76 to $1.02 \mathrm{t} \mathrm{ha}^{-1}$ ). In 2004/05 (301 mm rainfall)
\end{abstract}

Responsible Editor: Liz Stockdale.

B. Ncube $(\bowtie) \cdot$ M. T. van Wijk $\cdot$ K. E. Giller

Plant Production Systems, Department of Plant Sciences, Wageningen University,

6700 AK, P.O. Box 430, Wageningen, The Netherlands

e-mail: bongisto@yahoo.com

e-mail: Bongani.Ncube@wur.nl

B. Ncube $\cdot$ S. J. Twomlow $\cdot$ J. P. Dimes

International Crops Research Institute for the Semi-Arid Tropics (ICRISAT),

P.O. Box 776, Bulawayo, Zimbabwe most legume yields were less than $0.5 \mathrm{tha}^{-1}$, except for pigeon pea. Estimates of $\% \mathrm{~N}$ from $\mathrm{N}_{2}$-fixation from the legumes were $15-50 \%$ (2002/03), 16-61\% (2003/04) and 29-83\% (2004/05). Soil water changes during the legume growth cycle were proportional to varietal differences in total legume biomass. Sorghum grain yield after legumes reached up to $1.62 \mathrm{t} \mathrm{ha}^{-1}$ in 2003/04 compared with $0.42 \mathrm{t} \mathrm{ha}^{-1}$ when following sorghum. In 2004/05, sorghum yields after legumes were also higher (up to $1.26 \mathrm{t} \mathrm{ha}^{-1}$ ) than sorghum after sorghum. Incorporation of crop residues had no significant effect on sorghum yield. Beneficial effect of legumes on yields of the subsequent sorghum crop were more readily explained by improvements in soil nitrogen supply than by the small observed changes in soil water relations. Our results demonstrate clear potential benefits for increasing grain legume cultivation in semi-arid environments through the use of improved germplasm, which also gave substantial increases in subsequent sorghum productivity (up 200\% in a wet season and $30-100 \%$ in a dry season), compared with an unfertilized sorghum crop following sorghum.

Keywords Cereal $\cdot$ Crop rotation $\cdot$ Food security . Nitrogen fixation $\cdot$ Residues $\cdot$ Soil water

\section{Introduction}

In many semi-arid regions of sub-Saharan Africa farmers typically use monocultures of cereal crops 
such as sorghum (Sorghum bicolor (L.) Moench) and pearl millet (Pennisetum glaucum (L.) R.Br.), while use of intercropping and sound crop rotations is either erratic or infrequent. Continuous crop cultivation with a lack of fallows and limited input use has greatly decreased inherent soil fertility which is a fundamental impediment to agricultural growth and food production. Fertilizers tend to be expensive, unavailable and unaffordable for the predominant smallholder farmers in such regions of sub-Saharan Africa (Buresh and Giller 1998). Legumes provide these farmers with an important alternative to diversify their farming systems and improve soil fertility via symbiotic $\mathrm{N}_{2}$-fixation. Legumes also represent an important source of protein and supplemental income (Mapfumo and Giller 2001).

Sorghum and pearl millet are the main small grain cereals in the crop production system of the drier areas of semi-arid southern Africa, including Zimbabwe. Although yields of well-managed crops may range from 1.7 to $4.8 \mathrm{t} \mathrm{ha}^{-1}$, the average yields of sorghum and pearl millet in Zimbabwe are currently $0.6 \mathrm{t} \mathrm{ha}^{-1}$ or less (Ahmed et al. 1997; Rohrbach et al. 2005). There is a critical need to increase productivity to improve local food security. Currently legumes play a minor role in the cropping systems of the semi-arid environments (Ahmed et al. 1997) and they receive less than $5 \%$ of the soil fertility inputs (Mapfumo and Giller 2001). A better understanding of the opportunities for, and of the constraints to the inclusion of grain and forage legumes in farming systems under semi-arid conditions of sub-Saharan Africa is required (Mapfumo and Giller 2001; Twomlow 2004).

Residual yield benefits to cereal crops from previous grain legumes are well-documented in other tropical regions (Giller 2001). The positive responses of cereals following legumes have been attributed largely to enhanced availability of nitrogen $(\mathrm{N})$ to the cereal crop (Sanginga 2003). The N contribution to the cereal grown after the legume is largely dependent on how much of the $\mathrm{N}$ is removed and legumes with low $\mathrm{N}$ harvest indices thus have a greater potential for enhancing soil fertility (Giller and Cadisch 1995). Crop residues are commonly removed from the fields by farmers at harvest and stored for use as animal feed during the dry season.

Some studies attribute the residual benefits of legumes to other effects apart from nitrogen (Sauerborn et al. 2000; Sanginga 2003). Nielsen and Vigil (2005) indicated that soil moisture was an important factor in determining the residual benefits to cereals grown in rotation with green manure legumes in North America. Short duration, determinate legumes may result in more residual soil water for subsequent crops whereas long duration and/or indeterminate legumes may remove more water than cereal crops. In the face of restricted and uncertain rainfall, an improved understanding of the effects of legume-cereal rotations on water relations as well as $\mathrm{N}$ supply is required to evaluate the longer-term effects on soil productivity and yield stability of rotational systems.

The purpose of the study was to: (1) assess the productivity of indigenous and improved grain legumes under semi-arid conditions; (2) estimate $\mathrm{N}_{2}$ fixation and possible $\mathrm{N}$ accumulation in the soil; (3) quantify the residual benefits of legumes to sorghum grown in rotation; and (4) assess the water dynamics during the rotation.

\section{Materials and methods}

Environmental conditions and experimental design

Experiments were conducted at Lucydale research site located within the Matopos Research Station farm (28 $30^{\prime} \mathrm{E}, 20^{\circ} 23^{\prime} \mathrm{S}, 1,380 \mathrm{~m}$ above sea level) $45 \mathrm{~km}$ south of Bulawayo City. The soils of the site are classified as Eutric Arenosols (FAO/UNESCO) derived from granite (Moyo 2001). The upper slope consists of coarse grained, fersiallitic sandy clay loams while down slope soils are dominated by fersiallitic coarse grained loamy sands and light sandy loams (Hungwe et al. 1982). These soils are among the most common soil type cultivated by smallholder farmers in the communal areas of Zimbabwe (Mapfumo and Giller 2001), and in the drier south of the country tend to have more active clays than similar soils in the wetter north (Nyamapfene 1989) which are highly leached.

Eight short to medium duration legume varieties and one medium duration sorghum variety were selected for the experiments based on screening trials done during the previous seasons (Table 1). Sorghum was used as a reference crop during the legume phase.

Experimental treatments were replicated three times using a randomised complete block design and plot size was $20 \times 10 \mathrm{~m}$. Plots were split into two $10 \times$ $10 \mathrm{~m}$ subplots during the second season (sorghum crop). Residues (equivalent to plot stover yield in the 
Table 1 Crop characteristics and corresponding agronomic practices of experimental crops

\begin{tabular}{|c|c|c|c|c|c|c|c|c|c|}
\hline \multirow{2}{*}{$\frac{\text { Crop }}{\text { Variety }}$} & \multirow{2}{*}{$\begin{array}{l}\text { Sorghum } \\
\text { SV } 4\end{array}$} & \multicolumn{2}{|c|}{ Vigna unguiculata } & \multicolumn{2}{|c|}{ Arachis hypogaea } & \multicolumn{2}{|c|}{ Cajanus cajan } & \multicolumn{2}{|c|}{ Vigna subterranea } \\
\hline & & $\mathrm{CBCI}$ & 86D 719 & Nyanda & $\begin{array}{l}\text { Natal } \\
\text { Common }\end{array}$ & $\begin{array}{r}\text { ICEAP } \\
00535\end{array}$ & ICPL 98091 & $\begin{array}{l}\text { Cream } \\
\text { bambara }\end{array}$ & $\begin{array}{l}\text { Maroon } \\
\text { bambara }\end{array}$ \\
\hline Source & $\begin{array}{l}\text { AREX, } \\
\text { Matopos }\end{array}$ & $\begin{array}{l}\text { AREX } \\
\text { Harare }\end{array}$ & IITA Nigeria & $\begin{array}{l}\text { Seed } \\
\text { Co } \\
\text { Harare }\end{array}$ & $\begin{array}{c}\text { Seed Co } \\
\text { Harare }\end{array}$ & $\begin{array}{l}\text { ICRISAT } \\
\text { Kenya }\end{array}$ & $\begin{array}{l}\text { ICRISAT } \\
\text { Kenya }\end{array}$ & $\begin{array}{l}\text { Market } \\
\text { Bulawayo }\end{array}$ & $\begin{array}{l}\text { Market } \\
\text { Bulawayo }\end{array}$ \\
\hline $\begin{array}{l}\text { Growth } \\
\text { habit }\end{array}$ & - & Determinate & $\begin{array}{l}\text { Semi } \\
\text { determinate }\end{array}$ & - & - & Determinate & $\begin{array}{l}\text { Semi } \\
\text { determinate }\end{array}$ & - & - \\
\hline $\begin{array}{l}\text { Duration } \\
\text { (days) }\end{array}$ & $\begin{array}{l}\text { Medium } \\
(110- \\
120)\end{array}$ & $\begin{array}{l}\text { Short } \\
(60-90)\end{array}$ & $\begin{array}{l}\text { Short } \\
(60-70)\end{array}$ & $\begin{array}{c}\text { Short } \\
(70- \\
90)\end{array}$ & $\begin{array}{l}\text { Medium } \\
(140)\end{array}$ & Short (120) & Short (120) & Unknown & Unknown \\
\hline $\begin{array}{l}\text { Spacing } \\
(\mathrm{cm})\end{array}$ & $75 \times 15$ & $60 \times 25$ & $60 \times 25$ & $45 \times 20$ & $45 \times 20$ & $50 \times 20$ & $50 \times 20$ & $45 \times 30$ & $45 \times 30$ \\
\hline $\begin{array}{l}\text { Plant } \\
\text { population } \\
\left(\mathrm{m}^{-2}\right)\end{array}$ & 8.8 & 6.6 & 6.6 & 11.1 & 11.1 & 10 & 10 & 7.4 & 7.4 \\
\hline $\begin{array}{l}\text { Seed rate } \\
\left(\mathrm{kg} \mathrm{ha}^{-1}\right)\end{array}$ & 8 & 50 & 50 & 100 & 100 & 50 & 50 & 50 & 50 \\
\hline
\end{tabular}

legume phase) were incorporated into one of the subplots in July (2003/04 season) and October (2004/ 05 season) while the above-ground residues were removed from the second subplot.

Field measurements and crop management

Initial soil analysis was conducted to assess phosphorus (P) availability in the soil across the fields before starting the experiments. As $\mathrm{P}$ availability was low (Olsen $\mathrm{P}$ extraction $<0.1 \mathrm{mg} \mathrm{kg}^{-1}$ ), a blanket rate of $200 \mathrm{~kg} \mathrm{ha}^{-1}$ single super phosphate $\left(18 \mathrm{~kg} \mathrm{P} \mathrm{ha}^{-1}\right)$ was applied and ploughed in to a depth of $0.20 \mathrm{~m}$ prior to planting the legume phase each season. During the 2002/03 season, soil samples were collected from the $0-0.15,0.15-0.30,0.30-0.60$ and $0.60-0.90 \mathrm{~m}$ soil depths. During subsequent seasons a single layer, $0.30 \mathrm{~m}$, was sampled. Each soil layer was analysed for $\mathrm{pH}$ (water), organic carbon, total and available $\mathrm{P}$, and total $\mathrm{N}$. The methods used to analyse $\mathrm{pH}$, organic carbon and available $\mathrm{P}$ were those outlined by Okalebo et al. (1993), whereas nitrate N was analysed using the colorimetric method of Anderson and Ingram (1993).

Plant spacing was based on standard recommendations outlined in Table 1. Incorporation of the crop residues was done using a donkey drawn VS 200 mouldboard plough using a $0.20 \mathrm{~m}$ depth, a standard method used by local smallholders. Planting dates were; 19 December 2002 in the first season, 3 and 4 December 2003 in the second season, and 13 and 14 December 2004 in the third season. The first legume phase experiment was preceded by a millet breeding trial, the second by a 1-year fallow following a millet breeding trial and the third by a 2-year grass fallow. The overall experiment consisted of three seasons of legumes on three separate (but adjacent) experimental sites, two seasons of sorghum after legumes, and one legume-sorghum-sorghum sequence.

Local daily rainfall was measured throughout the cropping seasons. Soil water content was measured from the start of the 2002/03 season to the end of the 2003/04 cropping season. A Wallingford type neutron probe (Bell 1987) was used to measure soil water. Soil water measurements were taken once a week during the rainy season and biweekly or monthly during the dry season. Aluminium access tubes (45 $\mathrm{mm}$ internal diameter) were installed at the centre of each $10 \times 10 \mathrm{~m}$ subplot. The installation depth depended on the presence of an irregular weathered quartz layer and tube depths ranged from 0.49 to $0.9 \mathrm{~m}$ with an average depth across all experiments of $0.69 \mathrm{~cm}$. An additional tube was placed in a waterfilled plastic drum for a weekly water count to check for instrument drift and provide the value RW used in Eq. 1, prior to taking field readings. Measurements were taken at $0.1-\mathrm{m}$ increments, starting at $0.2 \mathrm{~m}$ below the soil surface. At each sampling date 
volumetric soil samples $(0.05 \mathrm{~m} \times 0.15 \mathrm{~m})$ were also collected from three positions in each plot to determine the volumetric water content of the surface layer $(0-0.15 \mathrm{~m})$, which cannot be measured accurately using the probe (Bell 1987). Neutron probe counts were converted to volumetric soil water content $(\theta)$ using the calibration curve for the Wallingford probe for sandy soils as outlined by Bell (1987). The equation for the curve is:

$\theta=0.790 R / \mathrm{RW}-0.024$

Where $R$ is the neutron probe count measured in the field and RW is the neutron probe count in a water filled drum. The volumetric soil water content was then converted to millimetres $(\mathrm{mm})$ of soil water in each layer and values were integrated over the experimental soil profile. The presence of an irregular weathered quartz layer in the soil profile caused different offsets between sub-plots within the same experimental site. To compensate for this variation in observed soil water contents, instead of calculating absolute soil water contents, the measurements were used to calculate changes in soil water storage relative to the absolute water content on day 1 of sampling in each plot. This is an accepted practice when variations in profile characteristics with depth influence water storage in the profile and prevent calibration of the neutron probe for absolute values (e.g. Farahani et al. 1998).

Crops were kept free of weeds, disease and pests throughout each growing season, although a severe outbreak of aphids affected the cowpeas during the 2003/04 cropping season. At maturity the middle six rows were harvested, with a $1 \mathrm{~m}$ border left at each plot end. Grain and stover were separated and subsamples were taken. The samples were dried at $70^{\circ} \mathrm{C}$ to constant weight and re-weighed to determine dry matter content and to calculate yield.

Nitrogen fixation was estimated using the ${ }^{15} \mathrm{~N}$ natural abundance method as outlined by Boddey et al. (2000). Samples of legumes and sorghum (grain and stover) were dried in the oven at $70^{\circ} \mathrm{C}$. The samples were then analysed for $\% \mathrm{~N}$ and ${ }^{15} \mathrm{~N}$ using a $20-20$ stable isotope mass spectrophotometer. Tissue ${ }^{15} \mathrm{~N}$ enrichment was calculated using Eq. 2:

$$
{ }^{15} \mathrm{~N}(\% / 00)=\frac{1000 \times\left(\text { atom } \%{ }^{15} \mathrm{~N} \text { sample }-0.3663\right)}{0.3663}
$$

The amount of $\mathrm{N}$ fixed was then calculated using Eq. 3:

$\% \mathrm{~N}$ from fixation $=$

$$
100 \times\left\lfloor\left(\delta^{15} \mathrm{~N}_{\text {referencecrop }}-\delta^{15} \mathrm{~N}_{\text {legume }}\right) / \delta^{15} \mathrm{~N}_{\text {referencecrop }}-\beta\right\rfloor
$$

With $\beta$ being the $\delta^{15} \mathrm{~N}$ of the legume when grown with $\mathrm{N}_{2}$ as the sole source of $\mathrm{N}$, and sorghum the reference crop. The $\beta$ values for groundnut, pigeon pea and cowpea were obtained from literature (Boddey et al. 2000). The $\beta$ value for groundnut was also used for Bambara groundnut.

The amount of $\mathrm{N}$ fixed was also calculated using the $\mathrm{N}$ difference method (Giller 2001). The method assumes that both legumes and the reference plants take up similar $\mathrm{N}$ amounts from the soil. Therefore, the difference between total $\mathrm{N}$ in the legume and $\mathrm{N}$ taken up by the reference plant (sorghum) is estimated to be equal to the total $\mathrm{N}$ fixed by the legume.

Statistical analysis

Grain, stover and $\mathrm{N}$ yield, and water data from both the legumes and sorghum were first tested for normality before carrying out analysis of variance (ANOVA) in Genstat 8.1. The legume varieties and season were the treatments in the legume analysis, while the replicates were the blocks. In the sorghum analysis residues were added as a third treatment. Standard errors of the differences (SED) of legume variety means are presented. Water data was also analysed using ANOVA.

\section{Results and discussion}

Initial soil characteristics

The soils at Lucydale were acidic (Table 2), but historically the acidity has had no drastic effect on crop growth at the site, possibly due to the fact that the clay fraction, although small, is still active (Nyamapfene 1989) and not as highly leached as the clay fractions of similar soils in wetter areas of the country. Total nitrogen contents were below the range for sandy clay loams $(0.06-0.10 \%)$ previously reported for upland soils of medium to low rainfall 
Table 2 Initial soil characteristics at the start of experimentation in each season

\begin{tabular}{|c|c|c|c|c|c|c|c|}
\hline Season & Soil depth (m) & $\mathrm{pH}$ & $\begin{array}{l}\text { Organic carbon } \\
\left(\mathrm{g} \mathrm{kg}^{-1}\right)\end{array}$ & $\begin{array}{l}\text { Available N } \\
\left(\mathrm{mg} \mathrm{kg}^{-1}\right)\end{array}$ & Total N (\%) & $\begin{array}{l}\text { Olsen } \mathrm{P} \\
\left(\mathrm{mg} \mathrm{kg}^{-1}\right)\end{array}$ & Total P (\%) \\
\hline \multirow[t]{4}{*}{$2002 / 03$} & $0-0.15$ & 3.7 & 7.8 & 7.3 & 0.04 & 12.2 & 0.10 \\
\hline & $0.15-0.30$ & 3.8 & 7.5 & 5.7 & 0.04 & 5.8 & 0.09 \\
\hline & $0.30-0.60$ & 4.8 & 5.9 & 1.5 & 0.03 & 2.2 & 0.08 \\
\hline & $0.60-90$ & 5.3 & 3.3 & 0.7 & 0.03 & 2.0 & 0.05 \\
\hline $2003 / 04$ & $0-0.30$ & 3.8 & 2.5 & 3.6 & 0.06 & 25.4 & 0.06 \\
\hline $2004 / 05$ & $0-0.30$ & 4.0 & 4.3 & 1.4 & 0.04 & 0.5 & 0.01 \\
\hline
\end{tabular}

Number of samples in the $0-0.30 \mathrm{~m}$ depth per season $=27$

In 2004/05 samples were collected before applying SSP fertilizer.

areas of Zimbabwe (Hungwe et al. 1982). The surface layer nitrate-nitrogen concentrations however tended to reflect the preceding cropping activity on the three sites, namely a millet breeding trial in season 1 (high), a fallow after a millet breeding trial in season 2 (less) and a grass fallow in season 3 (least). Organic carbon was below $1 \%$, and generally similar to that found in larger fields of the smallholder farming areas of Zimbabwe (Mtambanengwe and Mapfumo 2005; Zingore et al. 2006).

\section{Seasonal rainfall}

Rainfall was highly variable and subsequent cumulative rainfall values during the cropping season were 314, 650, and $301 \mathrm{~mm}$. Figure 1 shows cumulative daily rainfall measured across the three seasons.
The cropping season average total rainfall for Matopos (590 mm based on 50 year average) was exceeded only in the 2003/2004 season. A 'typical' rainy season in Matopos begins in late October/early November, and ends in April. During the 2002/03 season, enough rainfall for planting was received by 19 December 2002 and rainfall was evenly distributed until March after which crops matured under conditions of terminal drying. The 2003/04 rainy season started early in October and crops were planted on 3 and 4 December 2003. Ample rainfall during December and January allowed for good crop establishment during the critical growth stages while rainfall was also evenly distributed throughout the rest of the season (Fig. 1). The last season of experimentation (2004/05) had erratic rainfall. The rainy season started late and planting started in mid December (13 and 14). The
Fig. 1 Seasonal rainfall at Lucydale from the 2002/03 to the $2004 / 05$ season. The long-term average for Matopos weather station located at $5 \mathrm{~km}$ distance is about $590 \mathrm{~mm}$ per annum

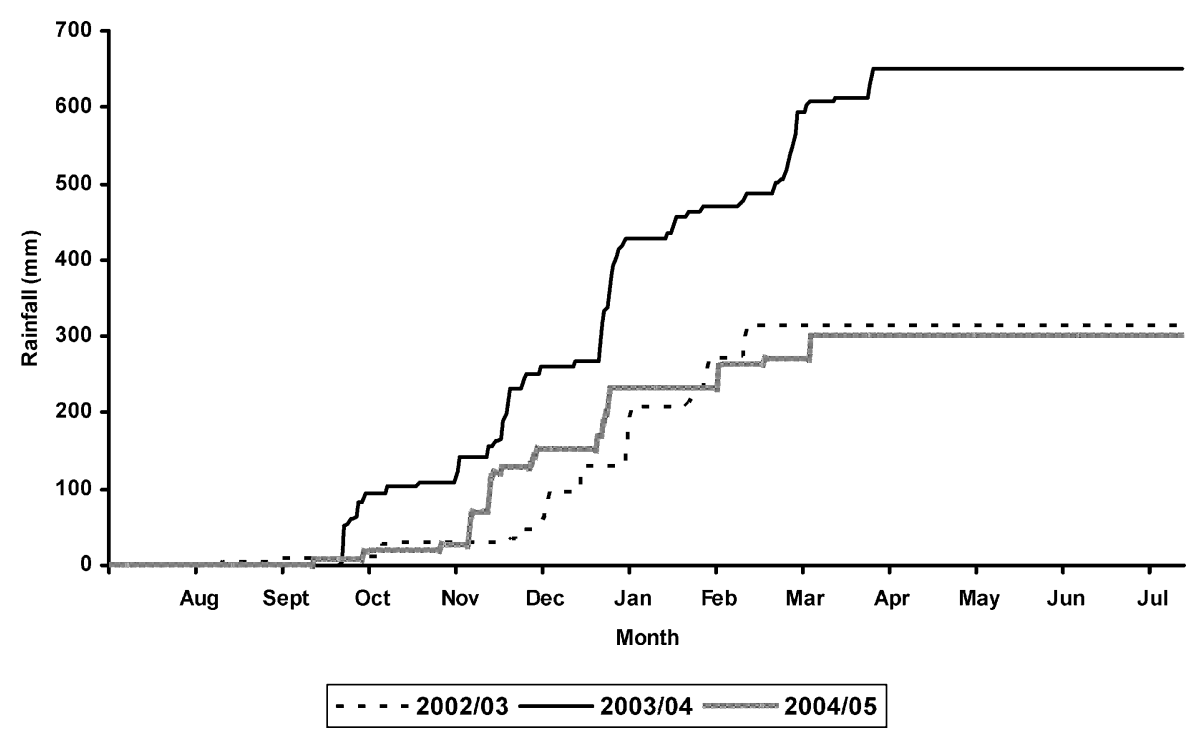




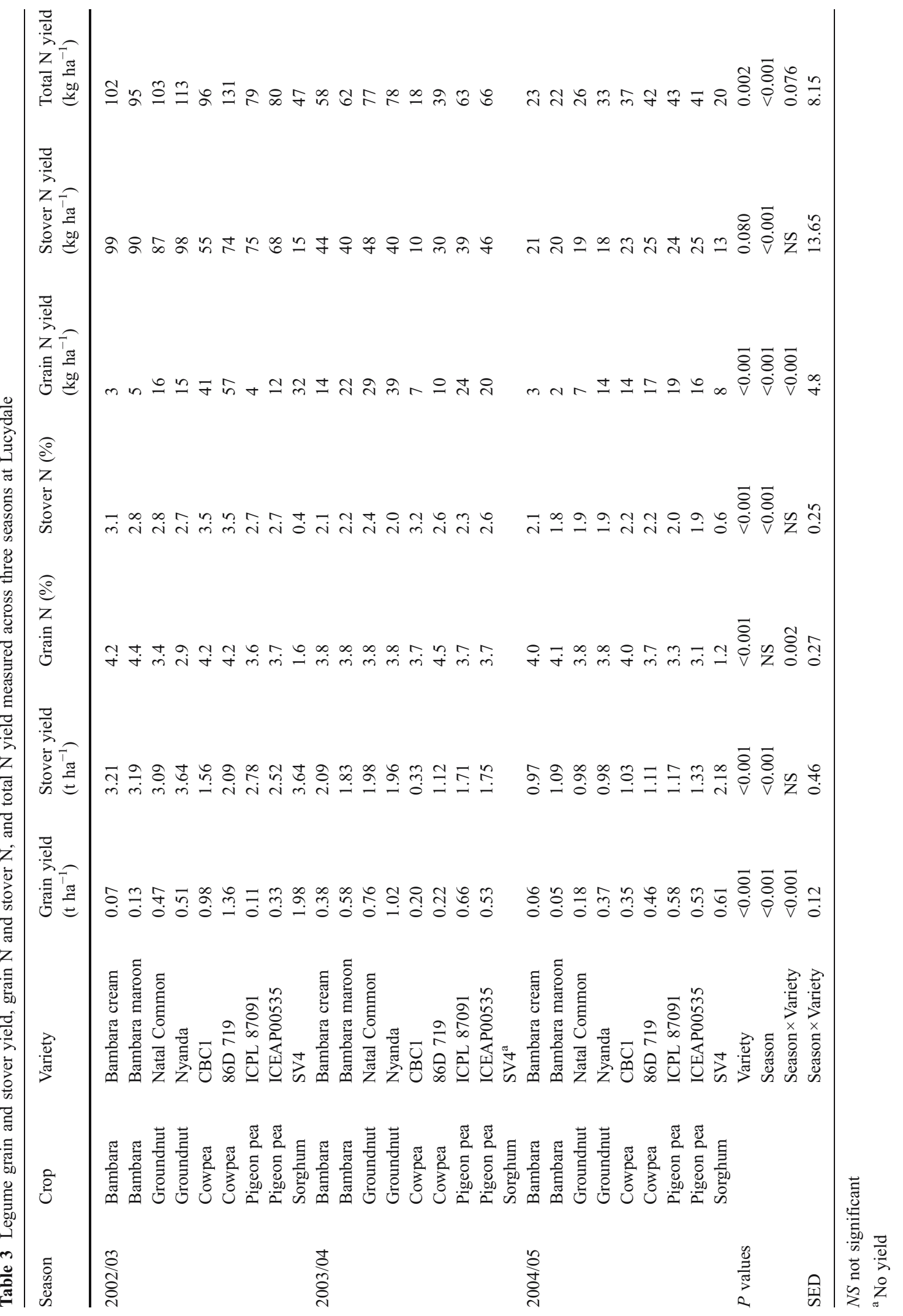


crops received only $24 \mathrm{~mm}$ in the first month of establishment while in January 2005 the rainfall total was $80 \mathrm{~mm}$, but the whole amount fell within 1 week (January 15-19). Thereafter only a few light showers were received.

\section{Legume grain yield}

Legume grain yields were significantly different across seasons $(P<0.001)$ and within seasons $(P<$ $0.001)$ when variety means were compared. All grain and stover yield weights are reported as oven dry values (Table 3). All legumes generally yielded higher than current reported yields in smallholder farms in dry regions, by about $20-300 \%$ except for the Bambara groundnut.

Cowpeas produced the highest grain yields during the dry 2002/03 season; CBCI $\left(0.98 \mathrm{t} \mathrm{ha}^{-1}\right)$ and 86D $719\left(1.36 \mathrm{t} \mathrm{ha}^{-1}\right)$. In a wetter 2003/04 season the cowpeas were severely attacked by aphids, resulting in poor grain yields. In 2004/05 cowpea produced 0.35$0.46 \mathrm{t} \mathrm{ha}^{-1}$. Average yields in smallholder farms in dry regions are currently $0.3 \mathrm{t} \mathrm{ha}^{-1}$ (Nhamo et al. 2003).

Groundnut yields were influenced by rainfall across the three seasons. The two groundnut varieties consistently exceeded $0.4 \mathrm{tha}^{-1}$, except in the 2004/5 season when Natal Common yielded only $0.2 \mathrm{t} \mathrm{ha}^{-1}$. The national average yields of groundnut in Zimbabwe's smallholder farming systems are also low $\left(0.3 \mathrm{t} \mathrm{ha}^{-1}\right.$; Nyakanda and Hildebrand 1999), but the yields we obtained were substantially better than smallholder farm yields of between 0.26 and $0.36 \mathrm{tha}^{-1}$ obtained in higher rainfall areas of the country (Waddington and Karigwindi 2001). Mupangwa and Tagwira (2005) suggested that groundnut yields could be improved through the use of phosphorus. Soil analysis and grain production results from smallholder farms in southwestern Zimbabwe have indicated that $\mathrm{P}$ is probably not a major limiting factor for legumes in the drier environment (Ncube et al. 2007). Therefore, the current poor groundnut yields in dry regions are probably more related to unimproved germplasm interacting with limited water availability rather than poor soil fertility per se.

Pigeon pea varieties consistently yielded more than $0.5 \mathrm{tha}^{-1}$ across the three seasons, although the variety ICPL 87091 performed poorly in 2002/03 where it produced $0.11 \mathrm{t} \mathrm{ha}^{-1}$. Pigeon pea is a relatively new crop in Zimbabwe. Mapfumo and Mtambanengwe
(2004) reported average yields of about $0.7 \mathrm{tha}^{-1}$ for the short duration variety ICPL 87109 in sub-humid eastern Zimbabwe. Chikowo et al. (2004) reported $\mathrm{pod} / \mathrm{seed}$ yields of less than $0.5 \mathrm{t} \mathrm{ha}^{-1}$ in the same higher rainfall region. The yield potential of pigeon pea is largely unknown in semi-arid regions of Zimbabwe, but the crop has so far shown potential in the region. The two varieties used in this experiment were selected because they had produced high yields of 0.8 (ICPL 87091 ) and 0.9 (ICEAP 00535) $\mathrm{t} \mathrm{ha}^{-1}$ on clay soils at the Matopos Research Station (Ncube et al. 2003).

Bambara groundnut performed very poorly in all three seasons, with maximum grain yield of 0.38 and $0.58 \mathrm{t} \mathrm{ha}^{-1}$ for the two cultivars in 2003/04. Bambara groundnut is an underutilized and largely unimproved crop that has received little attention from breeding programmes (Azam-Ali et al. 2001; Giller 2001). We used seed of landraces from the local market in our study. It is striking that Bambara groundnut performed so poorly in the two dry seasons (2002/03 and 2004/05), yet Collinson et al. (1996) suggested that Bambara groundnut is resistant to drought stress. Studies of the crop under semi-arid conditions in Botswana reported high grain yields of 0.4 to $1.5 \mathrm{t} \mathrm{ha}^{-1}$ (Karikari and Tabona 2004), though the crop was irrigated at emergence. The poor yields in our study were due to unimproved germplasm with consistently low harvest indices $(0.02-0.24)$ across seasons.

Legume nitrogen accumulation and $\mathrm{N}_{2}$-fixation

Nitrogen content in the grain was significantly different between the legume varieties $(P<0.001)$, while stover nitrogen content varied between both legume varieties $(P<0.001)$ and the seasons $(P<0.001)$. A high proportion of $\mathrm{N}$ that was produced by the legumes accumulated in the stover and was returned to the soil as residues. Legume $\mathrm{N}$ accumulation in stover at the end of the 2002/03 season was 87 and $98 \mathrm{~kg} \mathrm{ha}^{-1}$ (groundnut), 55 and $74 \mathrm{~kg} \mathrm{ha}^{-1}$ (cowpea), 75 and $68 \mathrm{~kg} \mathrm{ha}^{-1}$ (pigeon pea), 90 and $99 \mathrm{~kg} \mathrm{ha}^{-1}$ (Bambara groundnut). During 2003/04 overall N accumulation was less and the corresponding values were; 40 and $48 \mathrm{~kg} \mathrm{ha}^{-1}, 10$ and $30 \mathrm{~kg} \mathrm{ha}^{-1}, 39$ and $46 \mathrm{~kg} \mathrm{ha}^{-1}$ and 40 and $44 \mathrm{~kg} \mathrm{ha}^{-1}$ respectively. In the 2004/05 season the stover $\mathrm{N}$ yield values ranged between $18-25 \mathrm{~kg} \mathrm{ha}^{-1}$ (Table 3). These amounts were all greater than the amount of $\mathrm{N}$ accumulated in sorghum stover during the same period. Chikowo et al. (2003) 
reported net stover $\mathrm{N}$ addition of 82 and $17 \mathrm{~kg} \mathrm{ha}^{-1}$ for pigeon pea and cowpea respectively in a higher rainfall region of Zimbabwe. Kumar Rao et al. (1996) harvested $25-93 \mathrm{~kg} \mathrm{ha}^{-1} \mathrm{~N}$ from pigeon pea varieties in semi-arid India, whereas Toomsan et al. (1995) recorded $21-166 \mathrm{~kg} \mathrm{ha}^{-1} \mathrm{~N}$ in groundnut stover in farmers' fields in the northeast of Thailand. There is little information on Bambara groundnut $\mathrm{N}$ yields, but despite the low grain yield of Bambara groundnut in our study the amounts of $\mathrm{N}$ accumulated in stover were substantial in each of the three seasons.

The ${ }^{15} \mathrm{~N}$ signatures of sorghum (reference plants) were greater than the $\delta^{15} \mathrm{~N}$ signatures of all the legumes showing that the sorghum solely depended on soil $\mathrm{N}$ for its $\mathrm{N}$ uptake (Table 4). However, the short season cowpea variety $\mathrm{CBC} 1$ also gave relatively high $\delta^{15} \mathrm{~N}$ signatures (and correspondingly low fixation estimates). The highest signatures were recorded from the first experiment $(2002 / 03)$ when the three experiments were compared. Using the ${ }^{15} \mathrm{~N}$ natural abundance method we estimated that the legumes derived $15-50 \%(19-62 \mathrm{~kg} \mathrm{~N})$ of their $\mathrm{N}$ from $\mathrm{N}_{2}$-fixation in 2002/03: groundnut 19 and $41 \%$, cowpea 15 and $17 \%$, pigeon pea 28 and $30 \%$ and Bambara groundnut 34 and $50 \%$ (Table 4). In 2003/04 the legumes fixed 16-61\% (4-57 kg N ha ${ }^{-1}$ ) while in 2004/05 the legumes fixed 29-83\% (10-35 kg N ha $\left.{ }^{-1}\right)$. Chikowo et al. (2004) reported $84 \%$ (97 $\mathrm{kg} \mathrm{N} \mathrm{ha}^{-1}$ ) fixation for pigeon pea and $58 \%$ fixation $\left(28 \mathrm{~kg} \mathrm{~N} \mathrm{ha}^{-1}\right)$ for cowpea in subhumid eastern Zimbabwe. Similar proportions of $\mathrm{N}_{2}-$ fixation (45-68\%) have been reported in groundnut (Bell et al. 1994; Gathumbi et al. 2002), whereas in this study groundnut values ranged between 19 and $83 \%$ across the three seasons (Table 4).

The values of $\mathrm{N}$ derived from $\mathrm{N}_{2}$-fixation were similar to those calculated using the $\mathrm{N}$ difference method for most of the legumes in the 2003/04 and 2004/05 seasons, indicating that the ${ }^{15} \mathrm{~N}$ natural abundance method and the $\mathrm{N}$ difference method could give fairly similar estimates of $\mathrm{N}_{2}$-fixation even under dry conditions. However, the $\mathrm{N}$ difference estimates of $\mathrm{N}_{2}$-fixation were much higher in the 2002/03 season, particularly in the cowpea varieties and the groundnut Natal Common. It is not clear why the two methods differed so much during this season for these particular legumes. The differences were probably caused by high $\delta^{15} \mathrm{~N}$ values measured in samples from these legumes in 2002/03, but it is not clear why these high values arose.
The 2004/05 season had significantly less $N$ fixed (mean $23 \mathrm{~kg} \mathrm{~N}, P<.001$ ) compared to the other two seasons (means $39 \mathrm{~kg} \mathrm{~N}$ in 2002/03 and $38 \mathrm{~kg} \mathrm{~N}$ in 2003/04). The low $\mathrm{N}$ fixation in $2004 / 05$ was probably related to the poor rainfall distribution and plant moisture stress in that season. Symbiotic $\mathrm{N}_{2}$ fixation is highly sensitive to moisture stress (Ledgard and Steele 1992; Giller 2001). The persistently poor $\mathrm{N}_{2}$-fixation by $\mathrm{CBC} 1$ was probably also due to it being a determinate variety.

Rotation sorghum grain yield and nitrogen uptake

There was an overall increase in sorghum yield following legumes, even in the drier seasons (Table 5), while the yield increases over mono-cropped sorghum were on average $200 \%$ in the wetter $2003 / 04$ cropping season. In a drier 2004/05 season the yield increases were lower, but still more than $30 \%$ and up to $100 \%$ in a few plots. The response of sorghum to residual effects of legumes was strongly related to the previous legume variety in 2003/04 $(P<0.05)$.

Many studies of residual effects of legumes on subsequently planted cereals attribute yield benefit to $\mathrm{N}$ accumulation during the legume phase, and subsequent uptake by the following cereal (Giller 2001; Sanginga 2003). Cowpea and groundnut varieties accumulating most $\mathrm{N}$ during the 2002/03 season being generally followed by the highest yielding sorghum crop in 2003/04 seems to be in agreement with these findings (Tables 4 and 5). The highest sorghum yield in 2003/04 was $1.62 \mathrm{t} \mathrm{ha}^{-1}$, following Natal Common, sorghum after 86D 719 was $1.59 \mathrm{t} \mathrm{ha}^{-1}$. In general all legume varieties that accumulated substantial $\mathrm{N}$ during the legume phase showed relatively high yields of subsequent sorghum crops in the wetter 2003/04 season (Fig. 2). However, during the drier 2004/05 season there was no relationship between $\mathrm{N}$ yield in the previous season and sorghum grain yield showing that moisture availability was probably playing a more determinant role.

Some studies have demonstrated that residual effects of legumes cannot be attributed to contributions of $\mathrm{N}$ only. Other potential benefits include: a better supply of other nutrients such as cations like potassium, calcium and magnesium (Sauerborn et al. 2000); an N sparing effect (where legumes depend on fixed nitrogen and thus leave more available soil $\mathrm{N}$ to be taken up by the next crop: Herridge et al. 1995). A 


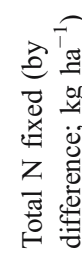

증ํㅇㅇำ

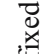

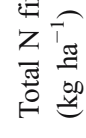

z

$\stackrel{0}{\circ}$

$\Xi \tau$

要

ㅂำ

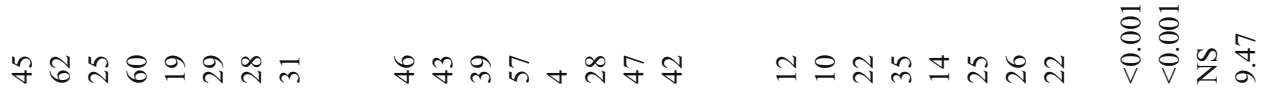

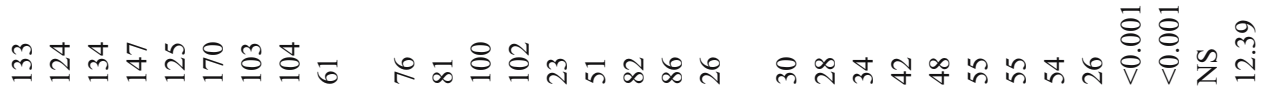

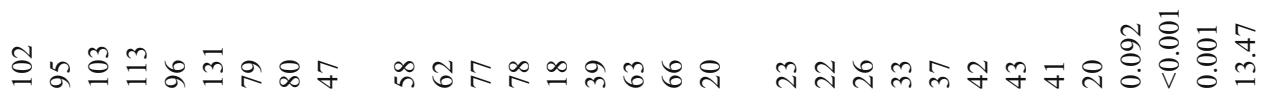

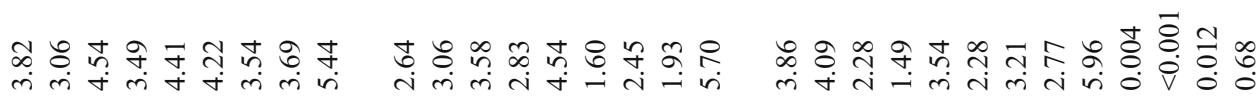

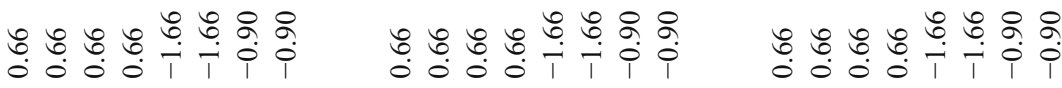

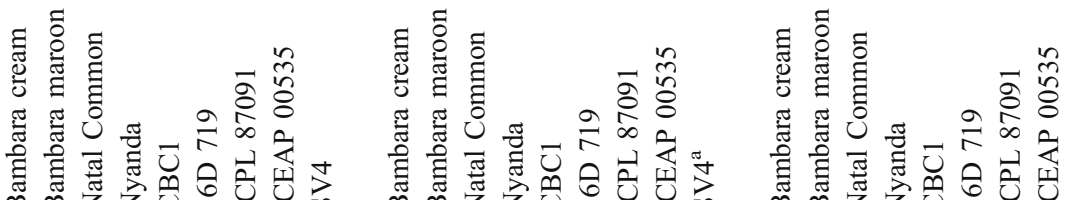

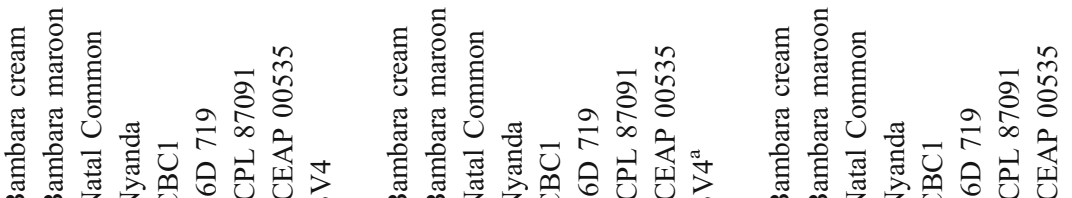

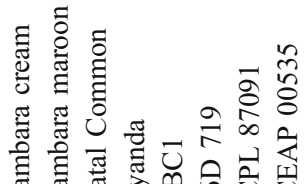

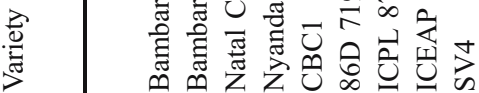

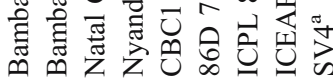

蒙蒙

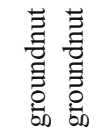

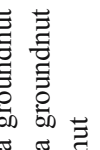

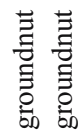

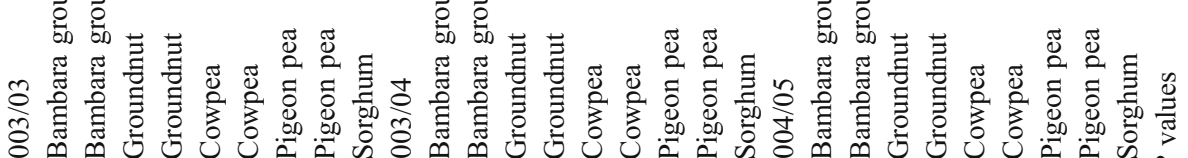

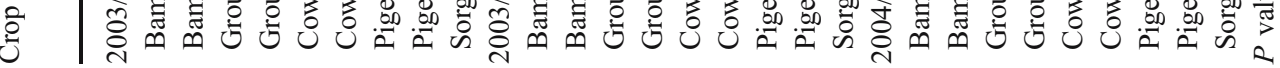

窐 


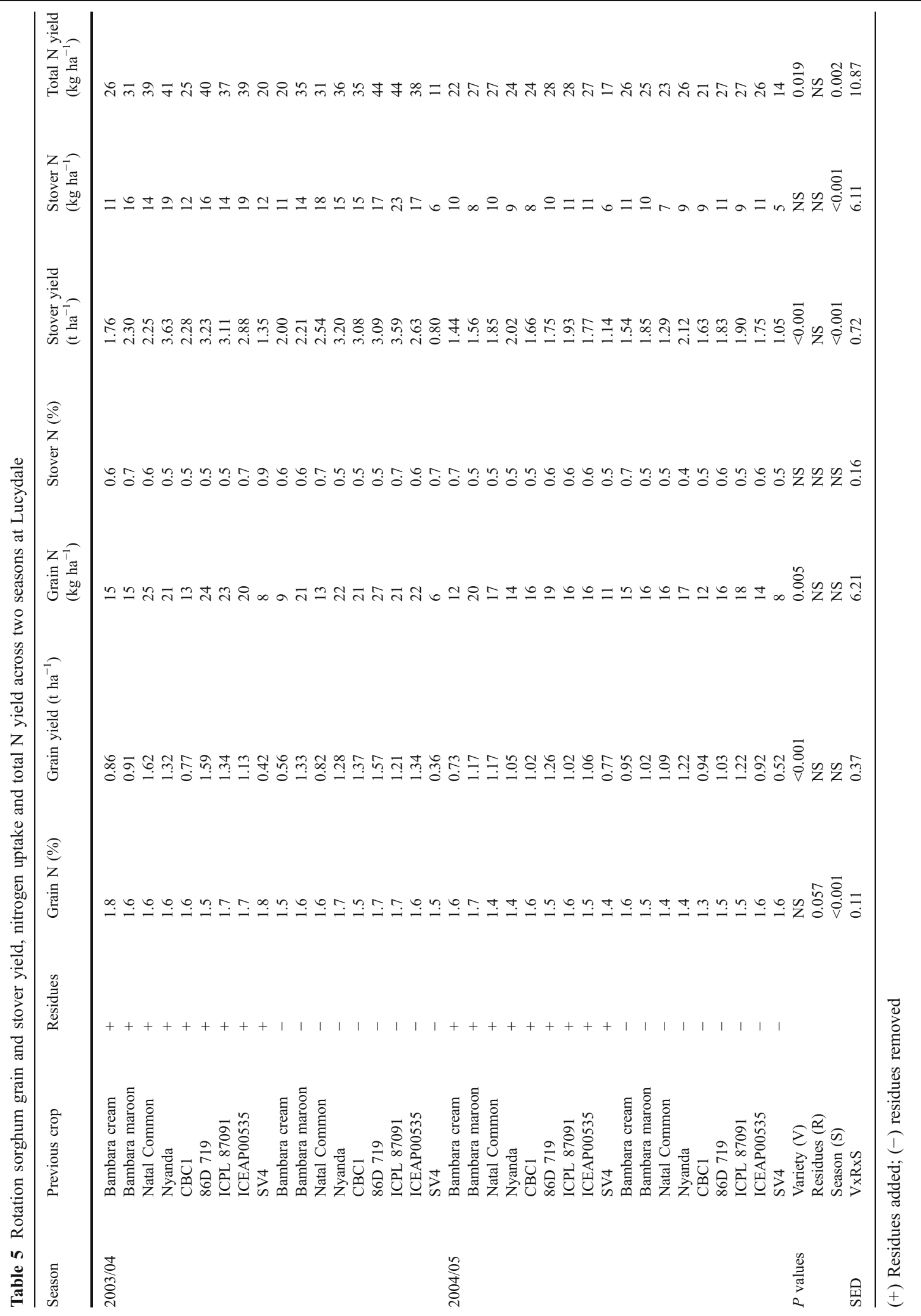


Fig. 2 Relationship between total nitrogen harvested during the legume phase and grain yield harvested during the sorghum phase at Lucydale for the 2003/04 and 2004/05 sorghum crops

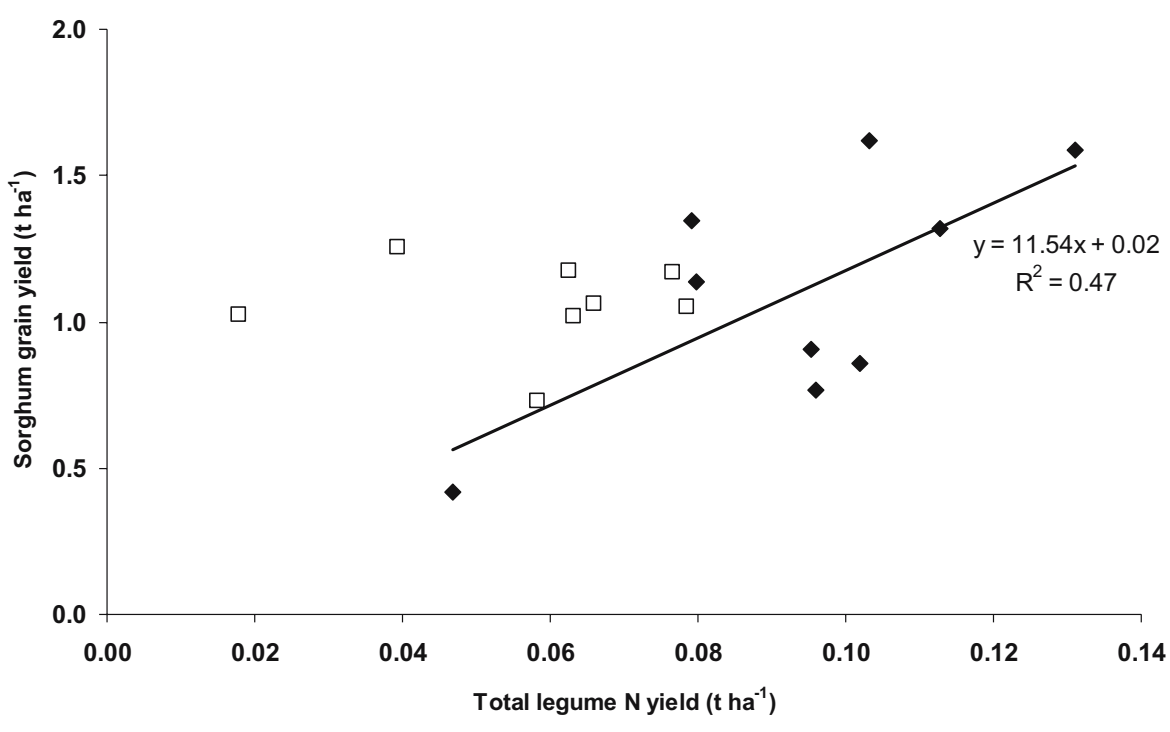

-2003/04 $\square 2004 / 05$

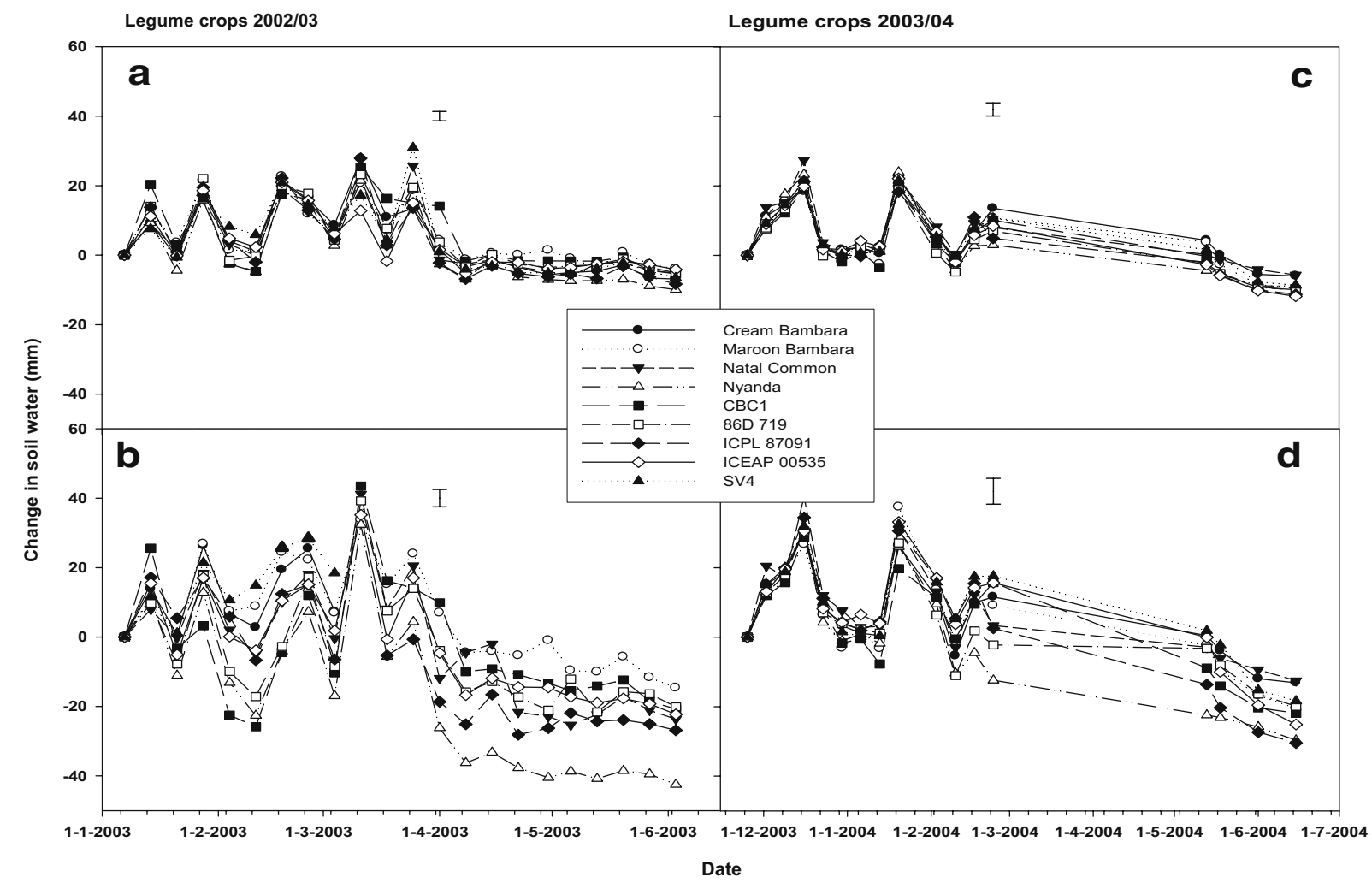

Fig. 3 Change in soil water during the legume phase of the 2002/03 cropping season [for the 0-25 (a) and 0-55 cm (b) soil layer] and the 2003/04 cropping season [0-25 (c) and 0-55 cm (d)]. Each point is an average of measurements in three plots. Error bars represent standard errors of differences between means of soil water changes for the varieties $(n=1,430)$ 


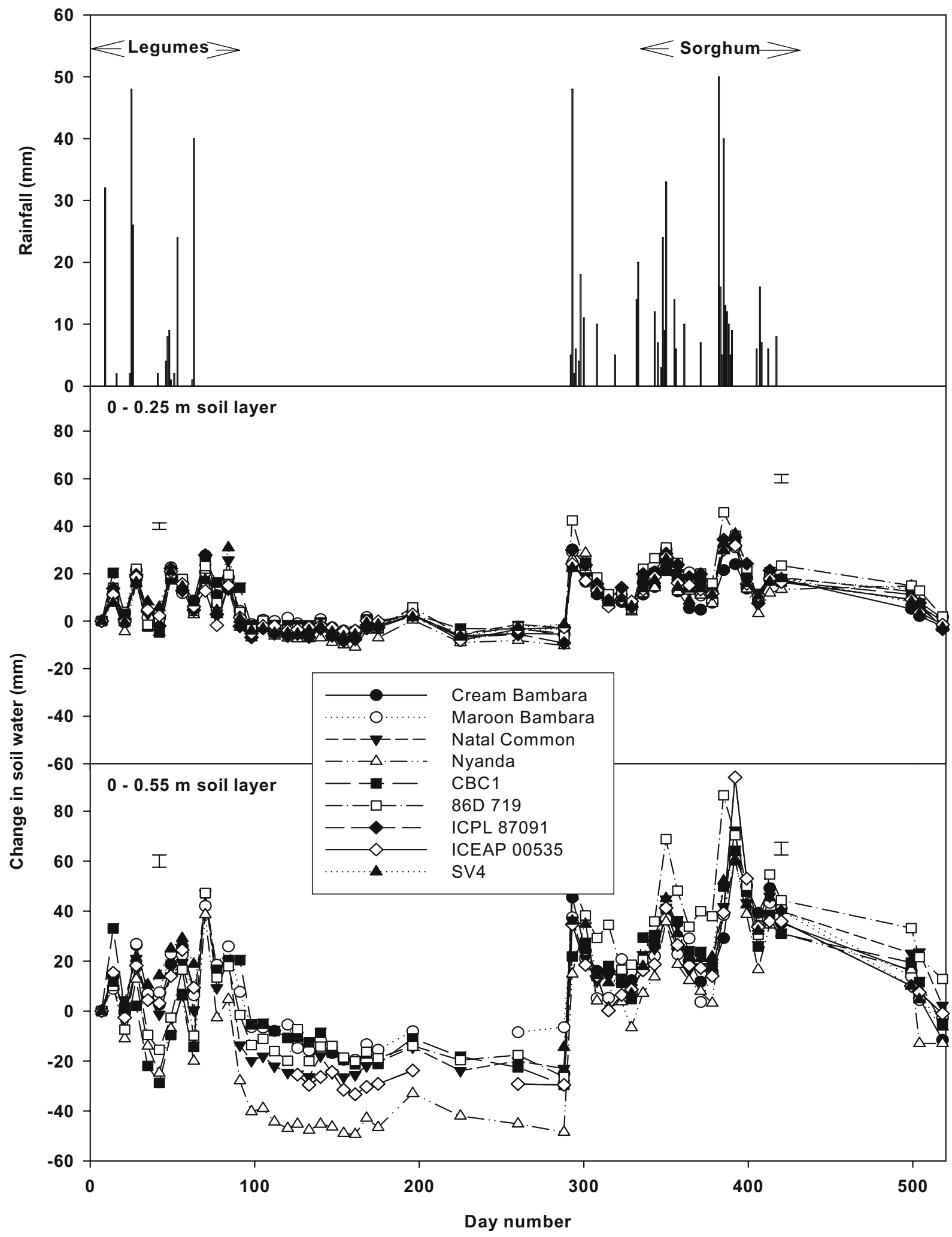


4 Fig. 4 Rainfall events and comparison of relative change in soil water during the 2002/03 (legume phase) and the 2003/04 (sorghum phase) cropping seasons for sorghum plots with no residues only. Each point is an average of measurements in three plots. Error bars represent standard errors of differences between means of soil water changes for the legume varieties $(n=459)$

further benefit could be arbuscular mycorrhiza infection and the suppression of root nematodes by legumes (Bagayoko et al. 2000).

The removal or addition of legume residues had no effect on sorghum yields (Table 5). Given the amount of $\mathrm{N}$ added to the plant-soil system with incorporated legume stover (up to $100 \mathrm{~kg} \mathrm{ha}^{-1}$ ), this is a surprising result. One explanation could be that the belowground $\mathrm{N}$ contribution and fallen leaves from the senescencing legumes supplied sufficient $\mathrm{N}$ to meet the requirements of the following sorghum crops.

Previous legume varieties had no effect on the N content of sorghum grain harvested in the subsequent season (Table 5). However, there were significant differences $(P<0.001)$ between seasons while residue removal resulted in a slight decrease in $\mathrm{N}$ content $(P=$ 0.057). The stover $\mathrm{N}$ content of sorghum was also not affected by residue removal. Total $\mathrm{N}$ accumulation was $35 \mathrm{~kg} \mathrm{ha}^{-1}(2003 / 04)$ and $26 \mathrm{~kg} \mathrm{ha}^{-1}(2004 / 05)$ in plots previously planted with legumes compared with 11 and $20 \mathrm{~kg} \mathrm{~N} \mathrm{ha}^{-1}(2003 / 04)$ and 14 and $17 \mathrm{~kg} \mathrm{ha}^{-1}$ (2004/05) for sorghum-based rotations. Differences were significant between previous legume varieties $(P<0.05)$ and seasons $(P<0.01)$.

There were weakly significant differences between the mean grain yields of the second sorghum crop ( $P=0.058$ ) during the $2004 / 05$ cropping season (data not shown). Sorghum grain yields after the legumes ranged from 0.7 to $1.5 \mathrm{t} \mathrm{ha}^{-1}$, whereas that of sorghum after sorghum was $0.9 \mathrm{tha}^{-1}$. The $\mathrm{N}$ content of grain was not affected by preceding crop varieties and residue handling in the second sorghum crop grown in 2004/05. However, stover N content was influenced by residue incorporation or removal two seasons prior in 2002/03. Sorghum grain and stover $\mathrm{N}$ content was generally greater in plots where residues were incorporated. As a result, total $\mathrm{N}$ accumulation by sorghum was also greatest in plots with residues. The yield was significantly different between previous variety $(P<0.05)$ and residue treatments $(P<0.05)$.
Soil water changes during the rotation

Soil water changes in the upper $0.25 \mathrm{~m}$ and $0.55 \mathrm{~m}$ soil layers during the legume phase were strongly influenced by legume variety and rainfall events during the cropping season for both years (Fig. 3a-d).

All legume varieties showed similar water use patterns in the upper $0-0.25 \mathrm{~m}$ soil layer in 2002/03 and 2003/04, and sorghum also closely followed the same pattern. The changes in water use were stronger in the relatively dry 2002/03 season (Fig. 3a,b) compared with the wetter 2003/04 season (Fig. 3c,d). However, for the deeper soil profile $(0-0.55 \mathrm{~m})$ legumes used more water during the growing period than sorghum (Fig. 3b,d). At the end of the growing period (April), varieties such as Nyanda and ICPL 87091 depleted more water from greater soil depths $(0.55 \mathrm{~m})$ than the other legume varieties. Nyanda had highest biomass production of legumes, whereas the pigeon pea variety ICPL 87091 was a long duration growing type.

The change in soil water during the sorghum phase did not show much dependence on the previous legume varieties in the $0-0.25 \mathrm{~m}$ soil layer (Fig. 4). The soil column in plots previously planted with legumes recharged to the same water content as with sorghum at the start of the rainy season in the upper layer. Even for the $0-0.55 \mathrm{~m}$ layer, observed differences in soil water content at the end of previous legume phase disappeared with the first single large rainfall event in October 2003, reflecting the low water holding capacity of the soil. Also noteworthy is the lack of differences in soil water use in the $0-0.55 \mathrm{~m}$ layer during growth of the sorghum crops, since there were quite large differences in sorghum biomass production between treatments (Table 5). However, the high and consistent rainfall in this season largely explains this observation. Whether or not similar effects would occur during seasons with poor initial and subsequent rainfall is an important question for further research, well suited to application of a calibrated cropping systems model (Ncube 2007).

\section{Conclusions}

Legume productivity was dependent on the variety grown and the amount and distribution of rainfall. New varieties of groundnut (Nyanda), cowpea (86D 719, 
CBC1) and pigeon pea (ICPL87091, ICEAP00535) were well adapted to the dry environments and yielded up to double or three times the grain yield achieved with traditional varieties. The legumes also fixed large proportions of their $\mathrm{N}$ from the atmosphere. Legume plots that produced the highest total $\mathrm{N}$ yield generally enhanced $\mathrm{N}$ supply and sorghum grain yields in the subsequent cropping season, by up to $200 \%$ in a wet season and 30 to $100 \%$ in a very dry season. All plots showed similar water recharge at the start of the sorghum phase indicating that the legumes had little direct impact on soil water storage to the following sorghum for this soil type. There is need to further study water dynamics in the rotation in order to fully understand the interactions between water and $\mathrm{N}$ use. The long-term bio-economic sustainability of the rotations also needs further assessment.

Acknowledgements The authors are grateful to the Netherlands Foundation for Science in the Tropics (WOTRO) and the International Crops Research Institute for the Semi-Arid Tropics (ICRISAT) for funding the research. We also thank Walter Mupangwa, Getrude Mpofu, Bhekimpilo Ncube and Vusumuzi Ndlovu.

\section{References}

Ahmed MM, Rohrbach DD, Gono L, Mazhangara E, Mugwira L, Masendeke DD, Alibaba S (1997) Soil Fertility Management in Communal Areas of Zimbabwe: Current Practices, Constraints and Opportunities for Change. Results of a Diagnostic Survey. Southern and Eastern Africa Region. Working Paper no 6

Anderson JM, Ingram JSI (1993) Tropical soil biology and fertility: a handbook of methods, 2nd edn. CAB International, Wallingford, UK, pp 221

Azam-Ali SN, Sesay A, Karikari SK, Massawe FJ, AguilarManjarrez J, Bannayan M, Hampson KJ (2001) Assessing the potential of an underutilized crop - A case study using Bambara groundnut. Exp Agric 37:433-472

Bagayoko M, Buerkert A, Lung G, Bationo A, Romheld V (2000) Cereal/legume rotation effects on cereal growth in Sudano-Sahelian West Africa: soil mineral nitrogen, mycorrhizae and nematodes. Plant Soil 218:103-116

Bell JP (1987) Neutron Probe Practice. Report No. 19, 3rd edn. Institute of Hydrology, Wallingford, England, pp 51

Bell MJ, Wright GC, Suryantini, Peoples MB (1994) The $\mathrm{N}_{2^{-}}$ fixing capacity of peanut cultivars with differing assimilate partitioning characteristics. Aust J Agric Res 45:14551468

Boddey RM, Peoples MB, Palmer B, Dart PJ (2000) Use of the N15 natural abundance technique to quantify biological nitrogen fixation by woody perennials. Nutr Cycl Agroecosyst 57:235-270
Buresh RJ, Giller KE (1998) Strategies to replenish soil fertility in African smallholder agriculture. In: Waddington SR, Murwira HK, Kumwenda JDT, Hikwa D, Tagwira F (eds.). Soil fertility Research for Maize-based Farming Systems in Malawi and Zimbabwe. Soil Fertility Network and CIMMYT, Harare, Zimbabwe, pp. 13-19

Chikowo R, Mapfumo P, Nyamugafata P, Nyamadzawo G, Giller KE (2003) Nitrate-N dynamics following improved fallows and maize root development in a Zimbabwean sandy clay loam. Agrofor Syst 59:187-195

Chikowo R, Mapfumo P, Nyamugafata P, Giller KE (2004) Woody legume fallow productivity, biological $\mathrm{N}_{2}$-fixation and residual benefits to two successive maize crops in Zimbabwe. Plant Soil 262:303-315

Collinson ST, Azam-Ali SN, Chavula KM, Hodson DA (1996) Growth, development and yield of Bambara groundnut (Vigna subterranea) in response to soil moisture. J Agric Sci 126:307-318

Farahani HJ, Peterson GA, Westfall DG, Sherrod LA, Ahuja LR (1998) Soil water storage in dryland cropping systems: the significance of cropping intensification. Soil Sci Soc Am J 62:984-991

Gathumbi SM, Cadisch G, Giller KE (2002) N-15 natural abundance as a tool for assessing $\mathrm{N}_{2}$-fixation of herbaceous, shrub and tree legumes in improved fallows. Soil Biol Biochem 34:1059-1071

Giller KE (2001) Nitrogen fixation in tropical cropping systems. CAB International, Wallingford, UK

Giller KE, Cadisch G (1995) Future benefits from biological nitrogen fixation: an ecological approach to agriculture. Plant Soil 174:255-277

Herridge DF, Marcellos H, Felton WL, Turner GL, Peoples MB (1995) Chickpea increases soil $\mathrm{N}$ fertility in cereal systems through nitrate sparing and $\mathrm{N}_{2}$-fixation. Soil Biol Biochem 27:545-551

Hungwe A, Hopkins M, Garikayi A (1982) The Soils of Matopos Research Station, Longsdale-Lucydale Block. Chemistry and Soils Research Institute. Soils Report No. 503. $\mathrm{CS} / 4 / 4 / 91$

Karikari SK, Tabona TT (2004) Constitutive traits and selective indices of Bambara groundnut (Vigna subterranea (L) Verdc) landraces for drought tolerance under Botswana conditions. Phys Chem Earth 29:1029-1034

Kumar Rao JVDK, Johansen C, Yoneyama T, Tobita S, Ito O (1996) Estimation of nitrogen fixation by the natural N15-abundance technique and nitrogen uptake by pigeonpea genotypes of different maturity groups grown in an inceptisol. J Agron Crop Sci-Z Acker-Pflanzenb 177: 129-138

Ledgard SF, Steele KW (1992) Biological nitrogen-fixation in mixed legume grass pastures. Plant Soil 141:137-153

Mapfumo P, Giller KE (2001) Soil Fertilty Management Strategies and Practices by Smallholder Farmers in Semi Arid Areas of Zimbabwe. International Crops Research Institute for the Semi Arid Tropics (ICRISAT) with permission from the Food and Agricultural Organization (FAO). Bulawayo, Zimbabwe and Rome, Italy, p 60

Mapfumo P, Mtambanengwe F (2004) Base nutrient dynamics and productivity of sandy soils under maize-pigeonpea rotational systems in Zimbabwe. In: Bationo (ed.) Managing Nutrient Cycles to Sustain Soil Fertility in Sub- 
Saharan Africa. Academy Science Publishers (ASP) in association with the Tropical Soil Biology and Fertility Institute of CIAT, Nairobi, pp. 225-238

Moyo M (2001) Representative Soil Profiles of ICRISAT Research Sites. Chemistry and Soil Research Institute. Soils Report No. A666. pp 97

Mtambanengwe F, Mapfumo P (2005) Organic matter management as an underlying cause for soil fertility gradients on smallholder farms in Zimbabwe. Nutr Cycl Agroecosyst 73:227-243

Mupangwa WT, Tagwira F (2005) Groundnut yield response to single superphosphate, calcitic lime and gypsum on acid granitic sandy soil. Nutr Cycl Agroecosyst 73:161-169

Ncube B (2007) Understanding Cropping Systems in the Semi-arid Environments of Zimbabwe: Options for Soil Fertility Management. PhD Thesis, Wageningen University, Wageningen, The Netherlands. 2007. ISBN: 908504-635-1

Ncube B, Manjala T, Twomlow S (2003) Screening of short duration pigeon pea in Matabeleland. In: Waddington SR (ed) Grain Legumes and Green Manures for Soil Fertility in Southern Africa: Taking Stock of Progress. Proceedings of a Conference held 8-11 October 2002 at Leopard Rock Hotel, Vumba, Zimbabwe. Soil fert Net and CIMMYTZimbabwe, Harare, Zimbabwe, pp 75-78

Ncube B, Dimes JP, Twomlow S, Mupangwa W, Giller KE (2007) Raising the productivity of smallholder farms under semi-arid conditions by use of small doses of manure and nitrogen: A case of participatory research. Nutr Cycl Agroecosyst 77:53-67

Nhamo N, Mupangwa W, Siziba S, Gatsi T, Chikazunga D (2003) The role of cowpea (Vigna unguiculata) and other grain legumes in the management of soil fertility in the smallholder farming sector of Zimbabwe. In: Waddington SR (ed) Grain Legumes and Green Manures for Soil Fertility in Southern Africa: Taking Stock of Progress. Proceedings of a conference held 8-11 October 2002 at the Leopard Rock Hotel, Vumba, Zimbabwe. Soil Fert Net and CIMMYT-Zimbabwe, Harare, Zimbabwe, pp 246
Nielsen DC, Vigil MF (2005) Legume green fallow effect on soil water content at wheat planting and wheat yield. Agron J 97:684-689

Nyakanda PN, Hildebrand GL (1999) Recommended Groundnut Production Practices for Smallholder Farmers in Zimbabwe. Causeway, Harare, Zimbabwe: Department of Research and Specialist Services, Ministry of Lands and Agriculture; and Harare, Zimbabwe: Seed Co Limited, pp 24

Nyamapfene KW (1989) Adaptation to marginal land amongst peasant farmers of Zimbabwe. J S Afr Stud 15:384-389

Okalebo RJ, Gathua KW, Woomer P (1993) Laboratory Methods of Soil and Plant Analysis: A Working Manual. Soil Science Society of East Africa. Marvel EPZ. Nairobi, Kenya

Rohrbach DD, Mashingaidze AB, Mudhara M (2005) The Distribution of Relief Seed and Fertilizer in Zimbabwe. Lessons Derived from the 2003/04 Season. FAO/ICRISAT, Zimbabwe

Sanginga N (2003) Role of biological nitrogen fixation in legume based cropping systems: a case study of West Africa farming systems. Plant Soil 252:25-39

Sauerborn J, Sprich H, Mercer-Quarshie H (2000) Crop rotation to improve agricultural production in sub-Saharan Africa. J Agron Crop Sci-Z Acker-Pflanzenb 184:67-72

Toomsan B, McDonagh JF, Limpinuntana V, Giller KE (1995) Nitrogen-fixation by groundnut and soybean and residual nitrogen benefits to rice in farmers fields in Northeast Thailand. Plant Soil 175:45-56

Twomlow SJ (2004) Increasing the role of legumes in smallholder farming systems - The future challenge. In Serraj R (ed) Symbiotic Nitrogen Fixation: Prospects for Application in Tropical Agroecosystems. Science Publishers, NH, USA, p 29-46

Waddington SR, Karigwindi J (2001) Productivity and profitability of maize plus groundnut rotations compared with continuous maize on smallholder farms in Zimbabwe. Exp Agric 37:83-98

Zingore S, Murwira HK, Delve RJ, Giller K (2006) Influence of nutrient management strategies on soil variability, crop yields and nutrient balances on smallholder farms in Zimbabwe. Agric Ecosyst Environ 119:112-126 